\begin{tabular}{|l|l|l||}
\hline \multicolumn{2}{|c|}{ PublisherInfo } \\
\hline \hline PublisherName & $:$ & BioMed Central \\
\hline \hline PublisherLocation & $:$ & London \\
\hline \hline PublisherImprintName & $:$ & BioMed Central \\
\hline \hline
\end{tabular}

\title{
CD40 ligand blockade
}

\begin{tabular}{|l|l|l||}
\hline \multicolumn{2}{|c|}{ ArticleInfo } \\
\hline \hline ArticleID & $:$ & 205 \\
\hline \hline ArticleDOI & $:$ & $10.1186 /$ ar-2000-66783 \\
\hline \hline ArticleCitationID & $:$ & 66783 \\
\hline \hline ArticleSequenceNumber & $:$ & 162 \\
\hline \hline ArticleCategory & $:$ & Paper Report \\
\hline \hline ArticleFirstPage & $:$ & 1 \\
\hline \hline ArticleLastPage & $:$ & 3 \\
\hline \hline & & RegistrationDate : 2000-2-21 \\
\hline ArticleHistory & $:$ & OnlineDate \\
\hline \hline ArticleCopyright & $:$ & Current Science Ltd2000-21 \\
\hline \hline ArticleGrants & $:$ & \\
\hline \hline ArticleContext & $:$ & 130753311 \\
\hline \hline
\end{tabular}


Aff1 United Medical and Dental Schools of Guy's and St Thomas'

Hospitals, London, UK

\section{Keywords}

\section{Autoimmunity, CD4, CD8, CD40 ligand, tolerance, transplantation}

\section{Context}

Much may be learnt about the suppression of autoimmunity using animal models of transplantation. The interaction between CD40 on B cells and CD40 ligand expressed predominantly by activated CD ${ }^{+}$ $\mathrm{T}$ cells plays an important role in the development of the humoral immune response and the induction of peripheral tolerance. Monoclonal antibodies against CD4 and CD8 have been shown to induce CD4-regulated tolerance of mismatched transplanted tissues in rodents. These regulatory $\mathrm{CD}^{+}{ }^{+}$cells also prevent the rejection of grafts, which co-express the antigens to which tolerance has been induced along with third party antigens. This phenomenon is known as linked suppression. The CD40/CD40L interaction is also an attractive target for immunotherapy, with the objective of inducing transplantation tolerance or the control of autoimmunity. To investigate whether nonlytic mAbs against CD40L induce tolerance to minor alloantigens in murine skin grafts, and whether linked suppression occurs in this system.

\section{Significant findings}

CBA/Ca mice treated perioperatively with MR1 demonstrated significant delay in graft rejection, but did not exhibit tolerance. This raised several questions. Were some cells involved in rejection not inhibited by anti-CD40L mAbs? Was the effect of MR1 temporary? Or was it permanent but new thymic emigres were becoming competent to reject? This led to the use of thymectomized mice in the study. These showed indefinite graft acceptance with MR1, but only following $\mathrm{CD} 8^{+} \mathrm{T}$ cell depletion. Thymectomized, $\mathrm{CD} 4^{+}$T cell depleted mice treated with MR1 showed delayed rejection (but not indefinite survival as in the athymic $\mathrm{CD}^{+} \mathrm{T}$ cell depleted animals). Tolerance was also induced in euthymic mice if MR1 was combined with anti-CD8 mAb. Studies of athymic, CD8 ${ }^{+}$-cell-depleted $\mathrm{CBA} / \mathrm{Ca}$ mice, treated with MR1 and first transplanted with B10.BR, showed subsequent long term 
acceptance of (AKR x B10.BR)F 1 grafts but rapid rejection of (AKR x CBA/Ca)F 1 grafts, showing that MR1-induced antigen-specific tolerance exhibited a dominant regulatory phenotype.

\section{Comments}

CD40 and CD40 ligand (CD40L) interactions play a critical role in regulating T-cell-dependent humoral immunity, the threshold for negative selection in the thymus and the induction of peripheral tolerance. Interruption of CD40/CD40L interaction in the periphery should increase the threshold for $\mathrm{T}$ cell and B cell activation, thereby decreasing autoreactivity or inducing transplantation tolerance. Clinical trials of anti-CD40L monoclonal antibodies (mAbs) are already in progress for active lupus. This study cautions that antibodies to CD40L alone may be insufficient to induce lasting tolerance, and that $\mathrm{CD}^{+} \mathrm{T}$ cell depletion is required. While this is true for alloantigens on a skin graft, it is possible that anti-CD40L mAb (MR1) or a different anti-CD40L antibody may successfully induce tolerance to the nuclear and cytoplasmic components that are prominent B cell autoantigens in lupus.

\section{Methods}

MR1 or placebo was administered perioperatively to CBA/Ca mice transplanted with multiple minor mismatched skin from B10.BR mice and the time to graft rejection measured. To investigate whether

MR1 could induce tolerance in $\mathrm{CD}^{+}{ }^{+} \mathrm{T}$ cells, $\mathrm{CBA} / \mathrm{Ca}$ mice were thymectomized and depleted of $\mathrm{CD} 8^{+}$ T cells. MR1, anti-CD4 mAb or no mAb was given perioperatively and B10.BR tailskin transplanted. After 70 days animals were rechallenged with a fresh graft. Further experiments to investigate the role of CD8 in rejection involved depletion of either $\mathrm{CD}^{+}$or $\mathrm{CD}^{+} \mathrm{T}$ cells in thymectomized CBA/Ca mice transplanted with B10.BR tailskin (half these mice were treated with MR1 as well). Seventy days after transplanting B10.BR tailskin, mice were rechallenged with a fresh B10.BR graft and a third party BALB/c graft. Finally, the development of linked suppression was assessed using athymic, CD ${ }^{+}$-celldepleted $\mathrm{CBA} / \mathrm{Ca}$ mice transplanted with $\mathrm{B} 10 . \mathrm{BR}$ under cover of MR1. They then received second grafts of (AKR x B10.BR)F1 + CBA/Ca tailskin or (AKR x CBA/Ca)F $1+$ B10.BR tailskin.

\section{References}

1. Honey K, Cobbold SP, Waldmann H: CD40 ligand blockade induces CD4 ${ }^{+} \mathrm{T}$ cell tolerance and linked suppression. J Immunol. 2000, 163: 4805-4810.

This PDF file was created after publication. 